\title{
Economic impact of COVID-19 pandemic in Armenia
}

\section{M.A. Voskanyan \\ Russian-Armenian University, Yerevan, Armenia; voskanyanm@gmail.com}

\begin{abstract}
Relevance. The world will certainly remember 2020 as a serious challenge in all aspects of human life. At the same time, while developed countries, despite the severity of the economic crisis, have sufficient reserves to help their economies go through the recovery growth, developing economies turned out to be the most vulnerable. This article describes the consequences of the COVID-19 pandemic for the Armenian economy from the point of view of the most critical factors that have determined the country's economic development over the past decade. Research objective. The key goal of the study was to try to identify and assess the economic consequences of the COVID-19 pandemic in Armenia. Data and methods. The study surveys macroeconomic indicators in Armenia over the past six months. The analysis is based on the statistical data characterizing the economic situation in Armenia and takes into account the key sectors of the economy as well as its weaknesses. Results. Some sectors of the Armenian economy will be very vulnerable to the crisis resulting from the COVID-19 pandemic. Conclusion. The main conclusion of the study is that at the moment the economic system of Armenia is at the stage of stagnation and, in the light of the pandemic, will move to the stage of economic recession in the medium term.
\end{abstract}

\section{KEYWORDS}

COVID 19 pandemic, economic consequences, macroeconomic policy, Armenian economy, anti-crisis measures of the Government of the Armenia

\section{FOR CITATION}

Voskanyan, M.A. (2020)

Economic impact of COVID-19 pandemic in Armenia. R-economy, 6(3), 183-195. doi: $10.15826 /$ recon.2020.6.3.016

\section{Экономические последствия COVID-19 для Армении}

\section{М.А. Восканян}

Российско-Армянский университет, Армения, Ереван; voskanyanm@gmail.com

\begin{abstract}
АННОТАЦИЯ
Актуальность. Текущий, 2020 год запомнится миру как серьезное испытание во всех аспектах человеческой жизни. Вместе с тем, если развитые страны, несмотря на степень тяжести экономического кризиса, обладают достаточными резервами, чтобы помочь экономикам пройти через восстановительный рост, то развивающиеся экономики в этом смысле оказались наиболее уязвимы. В данной статье сделала попытка оценки последствий пандемии COVID 19 для экономики Армении, с точки зрения наиболее уязвимых факторов, сопровождающих экономическое развитие в стране последнее десятилетие. Цель исследования. Определить и оценить экономические последствия пандемии COVID 19 в Армении. Данные и методы. Анализ основан на статистических данных, характеризующих экономическую ситуацию в Армении в последние 6 месяцев. В ходе анализа были учтены ключевые отрасли экономики, а также основные слабые звенья экономического развития страны. Результаты. По итогам исследования был сделан вывод, что некоторые секторы экономики Армении будут очень уязвимы перед серьезным кризисом в результате пандемии COVID 19. Вывод. Основным выводом исследования стал тезис о том, что в настоящий момент экономическая система Армении находится в стадии стагнации и в условиях пандемии перейдет в стадию экономического спада в среднесрочной перспективе.
\end{abstract}

\author{
КЛЮЧЕВЫЕ СЛОВА \\ пандемия COVID 19, \\ макроэкономическая \\ политика, экономика \\ Армении, антикризисные меры \\ Правительства PA
}

\section{ДЛЯ ЦИТИРОВАНИЯ}

Voskanyan, M.A. (2020)

Economic impact of COVID-19 pandemic in Armenia. R-economy, 6(3), 183-195. doi: 10.15826/recon.2020.6.3.016

\section{Introduction}

In research literature on developing economies and their potential growth, the institutional environment is described as one of the most significant problem points. Well-developed market institutions make it possible to minimize or reduce losses from crises that arise from time to time in the economy (Honorati et al., 2020; Mishra, 2020; Ozili \& Arun, 2020). Obviously, it is impossible to ensure sustainable rates of economic growth in the long term by means of state regulation alone and without the participation of a healthy insti- 
tutional environment (Antinyan et al., 2020). The case of the 2020 pandemic illustrates this thesis very well. The whole world is experiencing and will continue to experience the economic consequences of the current situation for a long time. However, the stronger the economy is institutionally and the richer is the state budget of the country, the easier it is to cope with the consequences of the crisis, especially the crisis of this scale. $\mathrm{Nu}-$ merous studies already point to the serious economic decline looming in the near future (Buck et al, 2020; Furmanet al., 2020). The world has seen a significant decline in trade flows, not to mention a decline in tourism. Some authors argue that the first sector to be affected is the domestic and foreign trade turnover of countries (Brodeur et al., 2020; Conti et al., 2020).

The specificity of the current situation is that in addition to the fact that the crisis will affect almost all countries of the world, it is structurally very different from the previous crises that the world economy has seen. As you know, forced quarantine, by and large, completely froze some sectors of the economy (tourism, services, transport and many other industries). In the case of self-sufficient economies, such measures led to a serious crisis, which, however, is not irreversible. In the case of underdeveloped economies, especially those that are vulnerable to external shocks, the consequences of the crisis of 2020 could be irreversible. Forecasts of a fall in global GDP fluctuate within $-5 \%{ }^{1}$. At the same time, according to the same source, the leading economies will experience a drop in GDP by $1-4 \%$. Advanced economies will experience an 8\%-drop in GDP (World economic outlook update, 2020). At the same time, in countries with emerging markets, according to the IMF forecasts, a fall in GDP will not exceed $-3 \%$ (World economic outlook update, 2020). However, given that the pandemic is not over at the moment, it is difficult to make predictions with sufficient accuracy (Keogh-Brown et al., 2010; Jakson et al., 2020).

According to various estimates, in Armenia, GDP is likely to drop by $7-11 \%$, which enables us to estimate the damage inflicted by the pandemic. As of early April, according to some experts, the economic decline may already be more than $11 \%$, which is quite serious for Armenia ${ }^{2}$. Fore-

${ }^{1}$ Bloomberg Economics. https://www.bloomberg.com/ markets/economics

2 Armenian Banks. http://www.armbanks.am/2020/04/ $\underline{06 / 127957 \mid}$ casts from the Central Bank of Armenia are much rosier, and amount to no more than $4 \%^{3}$. The Armenian government also presents rather optimistic forecasts regarding the forthcoming fall. According to the forecast of the World Bank, GDP will fall by $2.8 \%$ (Global Economic Prospects, 2020, June). Thus, opinions and forecasts regarding the consequences of the pandemic for the Armenian economy differ significantly. Obviously, the real consequences can only be assessed in a year or two. However, even now one can see losses in certain sectors of the economy.

This research aims to assess the economic situation in Armenia in the light of such factors as slowing economic growth over the past ten years. The main objective of the study is to analyze the key drivers of the economic slowdown in terms of the pandemic's mid-term impact.

The main tasks of the research include the following:

1. Analyze the current macroeconomic situation in Armenia.

2. Identify the weakest sectors of the Armenian economy.

3. Recommend an anti-crisis program for the Government of Armenia.

4. Highlight the key sectors most affected by the pandemic-induced crisis.

\section{Results and Discussion}

The economic consequences of the current situation in the world can be significantly negative and long-term. Obviously, estimation of the real consequences at the moment does not seem to be reliable enough. However, we can already observe some changes in certain sectors, a decrease in per capita income, and the growth of unemployment. Entire sectors of the economy have been frozen and the recovery of some of them at the moment seems doubtful.

The Armenian economy from this perspective is a vivid example of the negative consequences of the COVID-19 pandemic. Of course, the last decade has been quite difficult for the Armenian economy in terms of development. The factors behind the slowdown in economic growth were institutional and deep-seated problems that most clearly manifested themselves during the 2007-2008 global financial crisis. Thus, the economic crisis caused by the 2020 pandemic found

${ }^{3}$ ARKA News Agency. http://arka.am/ru/news/economy/prognoz tsb armenii po ekonomicheskomu rostu ostaetsya neizmennym glava tsb/ 
the Armenian economy in an already weakened state, which means that the consequences for the country in the near future seem serious enough.

Within the framework of this study, we examined the key factors of the slowdown in economic growth in the light of intensified negative consequences of the 2020 crisis. From our point of view, it is important to identify the key vulnerable areas of Armenia's economy, which in turn will allow us, at a first approximation, to assess the upcoming risks associated with the consequences of the COVID-19 pandemic.

\section{Slowdown in economic growth}

Obviously, in the conditions of a slowdown in economic growth, any crisis affects the economy much more strongly. An already weakened economy is a more vulnerable system, and thus it is more susceptible to the negative effects of external and internal shocks. In this sense, the Armenian economy is in a rather risky position (Monitoring of the measures taken by the EAEU? 2020).

Figure 1 illustrates the recession over a decade that began in 2008-2009. Only by 2019 Armenia had managed to cross the 2008 GDP threshold (Fig. 1). Comparing the first two quarters of 2019 and 2020, we can observe a slight increase. However, given that quarantine measures in Armenia were introduced only in mid-March, the economic growth indicators for the first quarter cannot reflect the real consequences of the measures for the economy.

In this regard, we reviewed the Economic Activity Index, which has been calculated in Armenia since 2011. As we can see in Figure 2, the data for the last five months of 2020 indicate a certain

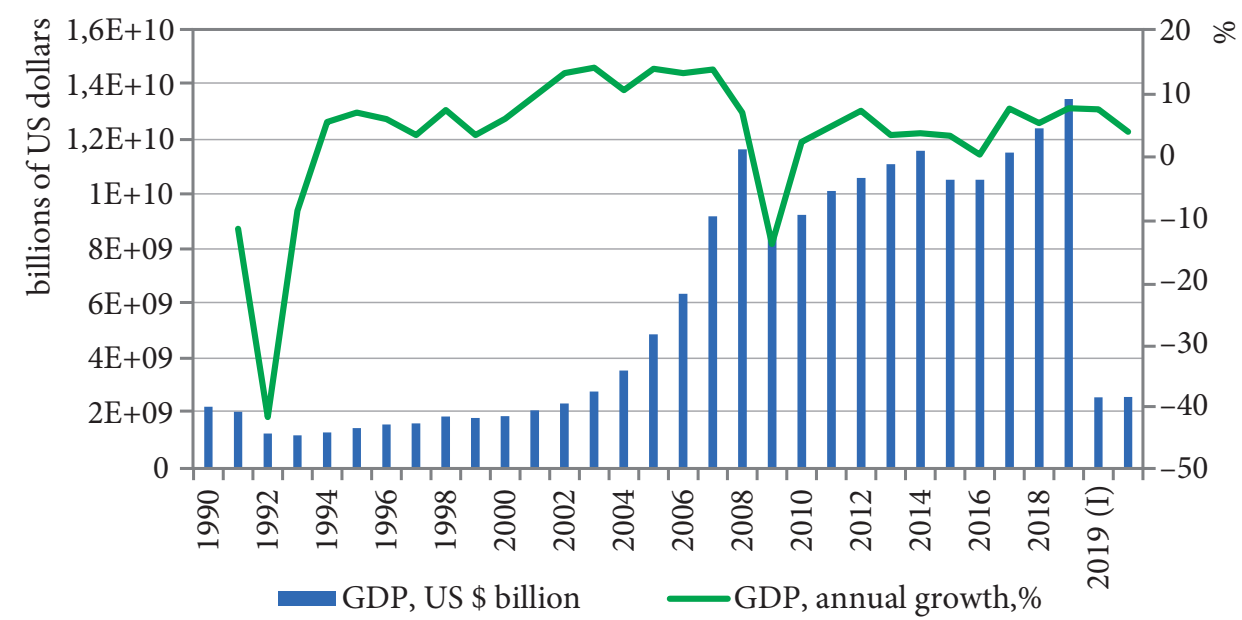

Figure 1. Economic growth in the Republic of Armenia, in billions of US dollars and \% Source: Database of NSS of Armenia www.armstat.am

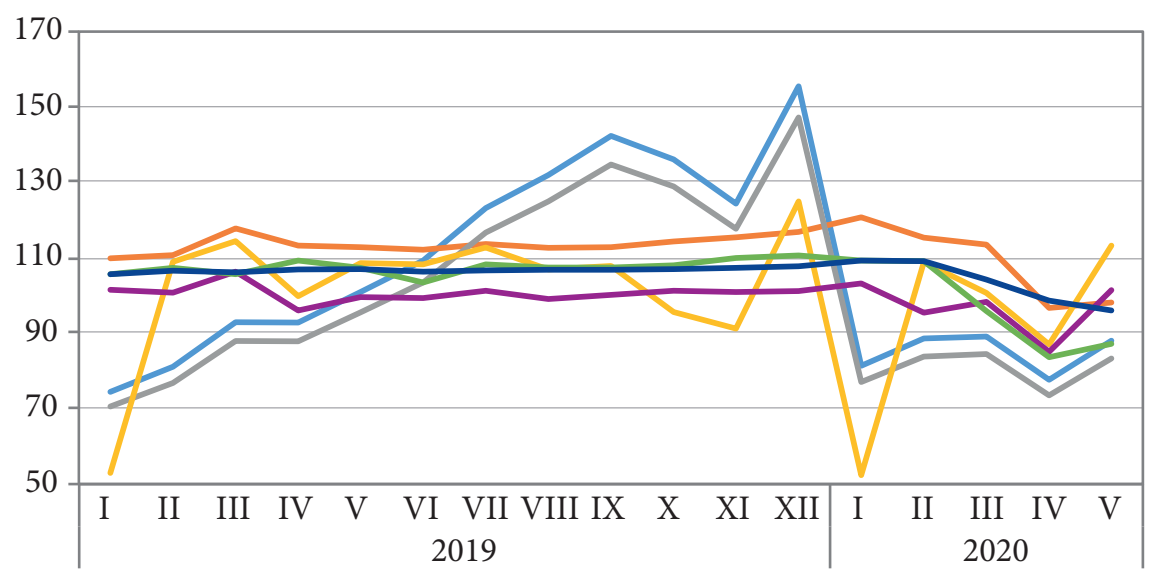

Chain Index, $2017=100$
Seasonal Chain Index $2007=100$
Chain Index, $2018=100$

Chain Index, $2018=100$

-Compared to previous month with seasonal accuracy

Compared to the same month of the previous year

- Compared to the same month of the previous year, accumulative

Figure 2. Index of economic activity of the Republic of Armenia, \% Source: Database of NSS of Armenia www.armstat.am 
decline, especially in the months when almost all economic activity was suspended. In almost all categories of the Economic Activity Index, we see a fall of $10-15 \%$ on average compared to the same period last year (Fig. 2).

It is also interesting to note that, in general, the decline has been observed since January, which may also indicate other reasons for the decline in economic activity indicators, not related to the consequences of the 2020 pandemic. To some extent, seasonal factors are important as well as the reduction of the most seasonally elastic sectors of the economy, for example, tourism, agriculture, etc.

\section{Low diversification of GDP structure}

Diversification of the economy is essential in terms of economic growth and development. Our research proves that the degree of diversification of the Armenian economy is at the level of average indicators (Voskanyan\& Galstyan, 2018). Today, as in many economies, the services sector accounts for the largest share of GDP (see Fig. 3). The share of agriculture and industry ranks second and third. As we can see from the results of the first six months of 2020, there is a significant reduction in the share of industry and agriculture in the structure of GDP, which is generally due to both quarantine measures and a reduction in demand in general against the background of the reduction or complete cessation of some economic activities in the country.

Thus, given the fairly large share of the service sector in the GDP structure, the Armenian economy, like many other developing economies, is in a rather vulnerable position from the point of view of the impact of external shocks.

Among the first to be hit by quarantine measures was trade. As we can see in Figure 4, the volume of total trade in Armenia decreased by $10.8 \%$

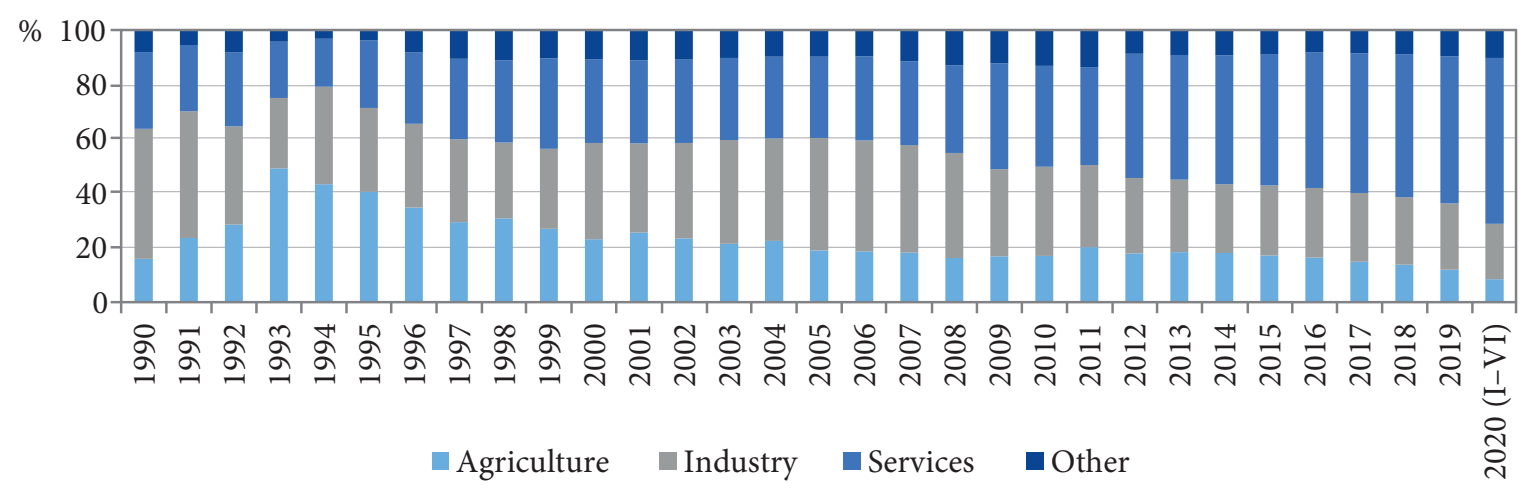

Figure 3. The structure of the Armenian GDP

Source: Database of NSS of Armenia www.armstat.am

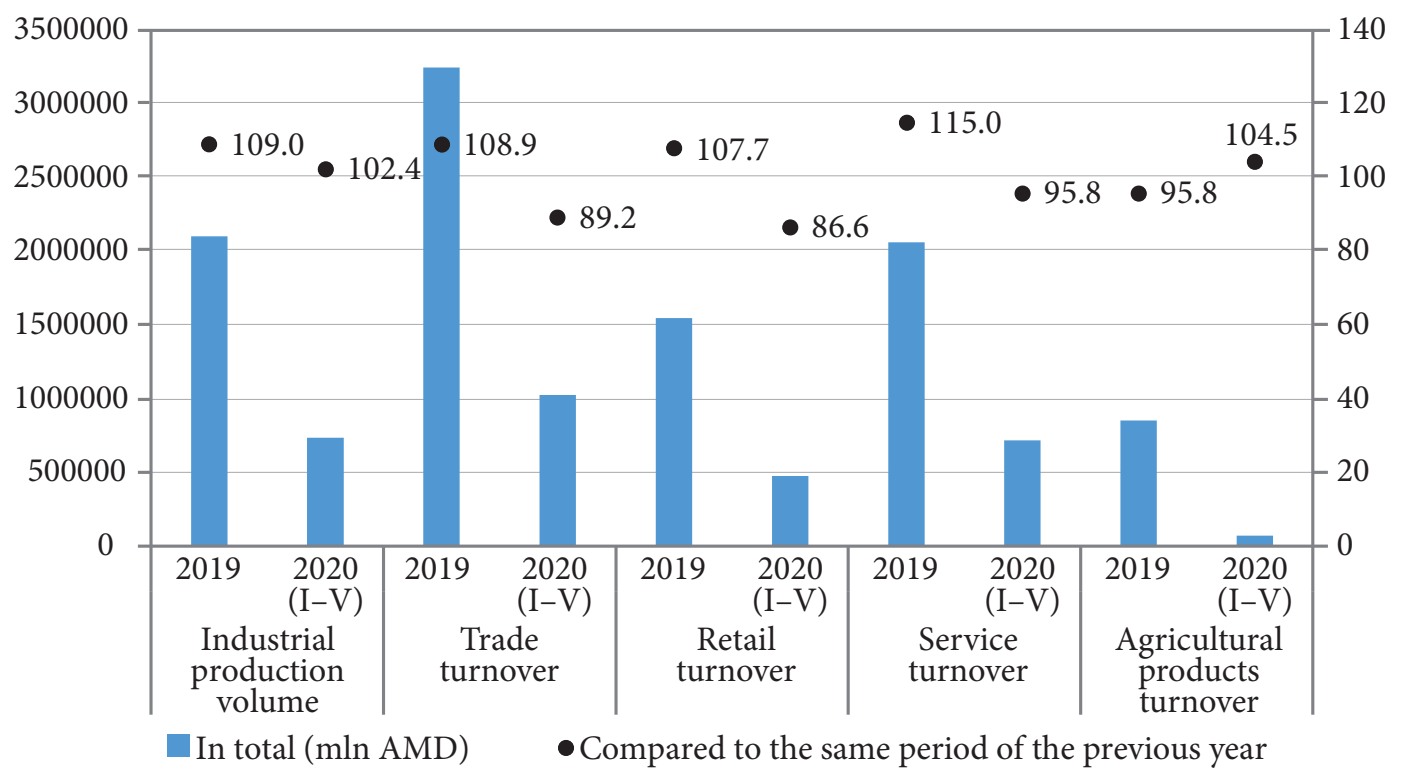

Figure 4. Volumes of various sectors of economic activity in Armenia, in AMD million and \% Source: Database of NSS of Armenia www.armstat.am 
compared to the same period of the previous year. The decline in retail trade has already amounted to $13.4 \%$, which will undoubtedly negatively affect the indicators for the whole year. The turnover of services in Armenia also underwent some reduction and amounted to $4.2 \%$ less than the volume of services recorded in the same period last year.

Along with the contraction of trade and the service sector, the turnover of industry and agriculture shows a certain growth. Thus, the volume of industry increased by $2.4 \%$ compared to the same period last year, while the volume of agricultural products increased by $4.5 \%$. Such dynamics inspire some optimism, although it is worth noting that, on average, growth in industrial production is lower compared to last year (SME Competitiveness Outlook, 2020). However, in the agricultural sector, on the contrary, there is a significant increase compared to the dynamics of 2019.

Nevertheless, the results of the first two quarters indicate a certain decline in most of the economy, which indicates the need for a more active anti-crisis policy on the part of the Government of Armenia.

\section{Negative trade balance}

The foreign trade turnover of Armenia has been characterized by negative balance values for many years. The high degree of import dependence of the Armenian economy makes it more sensitive to changes in the external environment. Closing borders between countries in the absence of their own resources that satisfy the primary demand from the population can be fraught with significant negative consequences.

As we can see in Figure 5, the first quarter of 2020 is characterized by a sharp drop in the country's trade turnover, both in terms of exports and imports, which of course was due to strict quarantine measures. These measures not only limited the movement of human resources, but also any other movement, including trade transportation. By the end of April and mid-May, trade traffic from and to Armenia was reduced to the required critical minimum (Monitoring of the measures taken by the EA member states, 2020).

As of the end of May, exports decreased by $8.1 \%$ compared to the same period last year. The largest decrease in exports is observed in April and is $28.8 \%$ of the indicators for the same period in 2019. In general, today the reduction in export positions compared with the 2009 crisis is a lower percentage, which allows us to expect a similar situation within this year.

As for imports, the results of the first five months of 2020 show that imports grew by $87.2 \%$ compared to the same period in 2019. The largest reduction in imports was again observed in April, when Armenia introduced lockdown measures and almost all economic activity was suspended for more than a month. The volume of imports in April amounted to $73.3 \%$ compared to the same periods last year, and in May this figure was $78.2 \%$.

Again, compared with the crisis of 2008-2009, when the reduction in imports was $25 \%$, and following the results of the crisis of 2014 with the reduction of $26.8 \%$, we can say that the first half

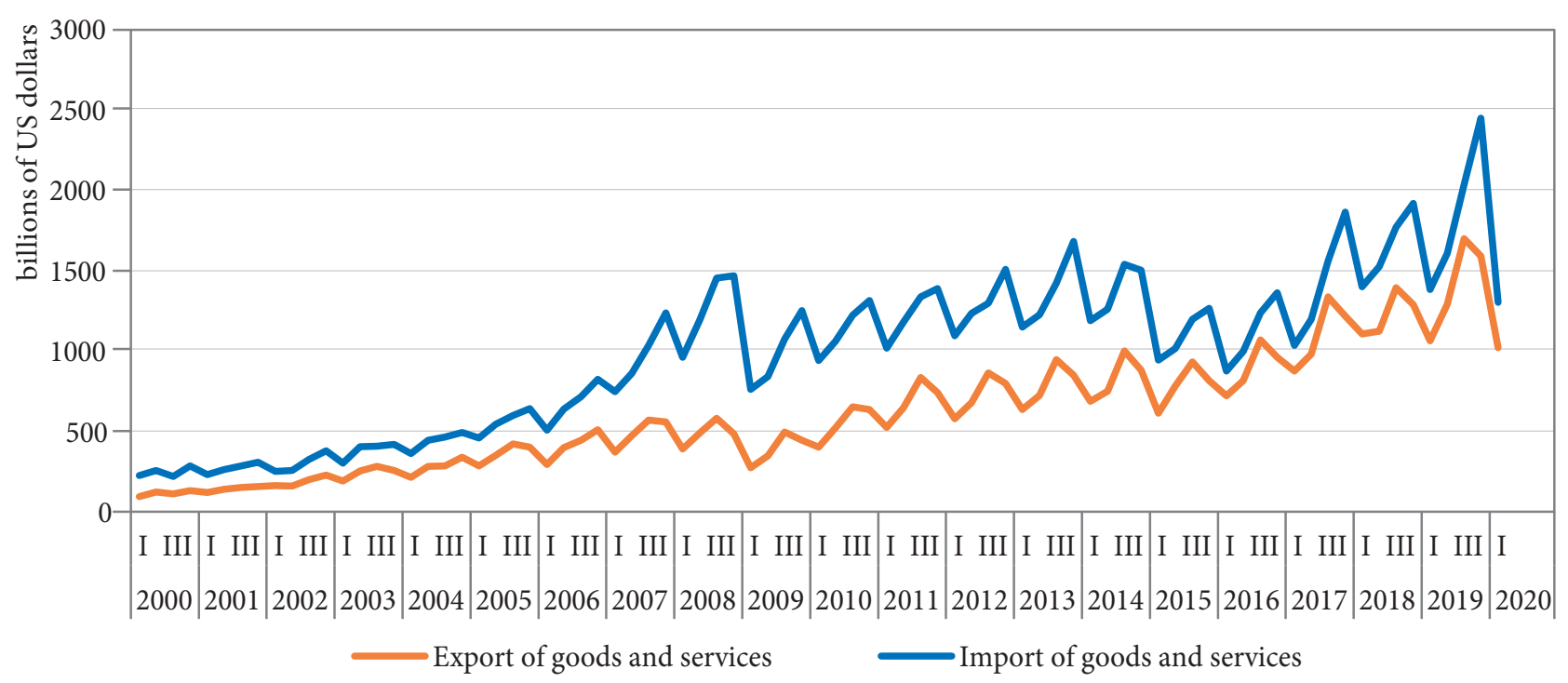

Figure 5. Export and import of goods and services of the Republic of Armenia, in billion US dollars Source: Database of NSS of Armenia www.armstat.am 
of 2020 is currently showing slightly better indicators. Given the weak positions of Armenia in the sphere of food security (grain crops and some other goods), in the long term, if the quarantine measures between the countries continue, this situation may result in significant threats to Armenia.

In general, Armenia's foreign trade turnover as of the end of May decreased by $11.2 \%$, which is better than the decline in $2009(-26.5 \%)$ and $2015(-20.9 \%)$. The largest decrease in foreign trade turnover was observed in April 2020 and amounted to $72.3 \%$ compared to the same period last year.

\section{Reduced investment}

Armenia has also faced a slight decrease in foreign direct investment, which in general is a natural consequence of the economic instability in the world over the past five six months (see Fig. 6).

At the same time, it should be noted that both the inflow and outflow of FDI have decreased, which may lead to the redirection of investment resources to local needs of the economy, and thereby increase the volume of domestic investment.

\section{Labor market inefficiency}

In many ways, the events of the past six months have prompted employers and governments to reconsider their approaches to labor regulation. It is no secret that many sectors of the economy were forced to make their workers redundant, both due to the lockdown, and in connection with the decrease in demand for a particular type of economic activity. In this sense, the Armenian economy was no exception.

The results of the first quarter show a decrease in the employment rate by $1.6 \%$ compared to 2019 (see Fig. 7). At the moment, there are no more recent data, however, from the available figures we can predict negative volatility in the labor market.

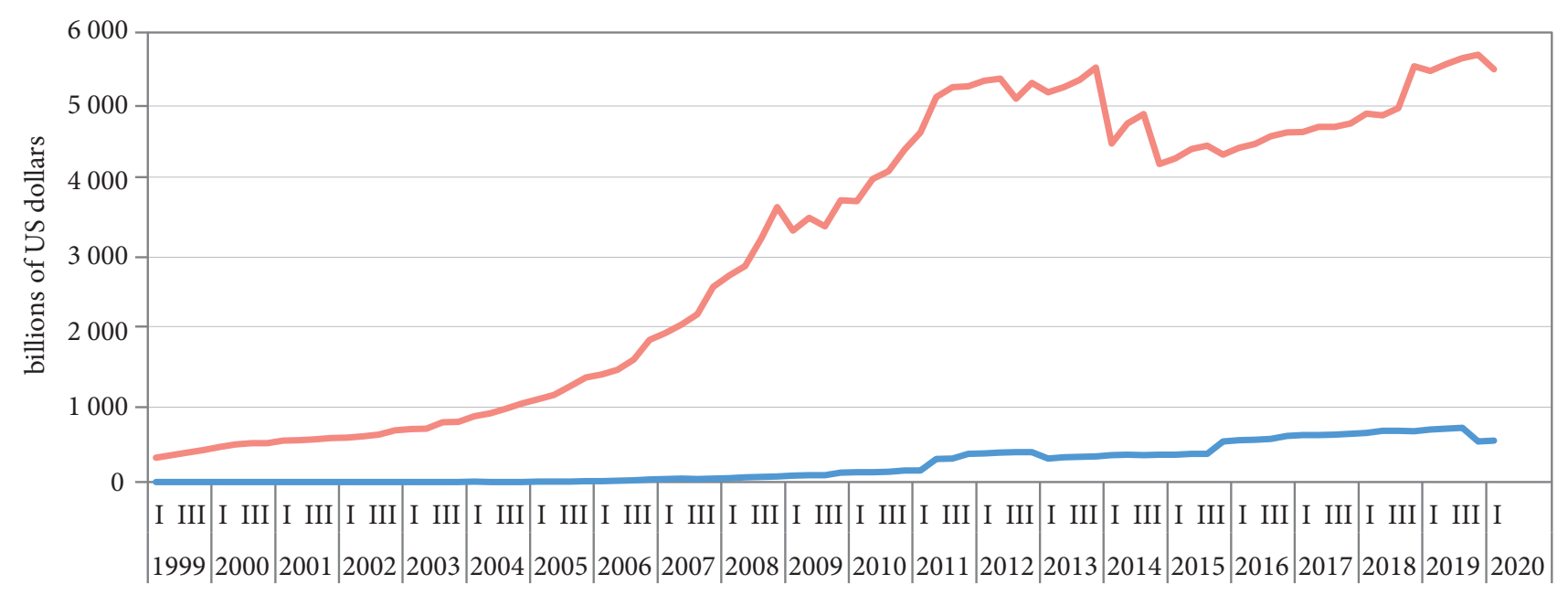

FDI, outflow FDI, inflows

Figure 6. Direct foreign investments in the Armenia, in billions of US dollars Source: Database of the Central Bank of Armenia www.cba.am

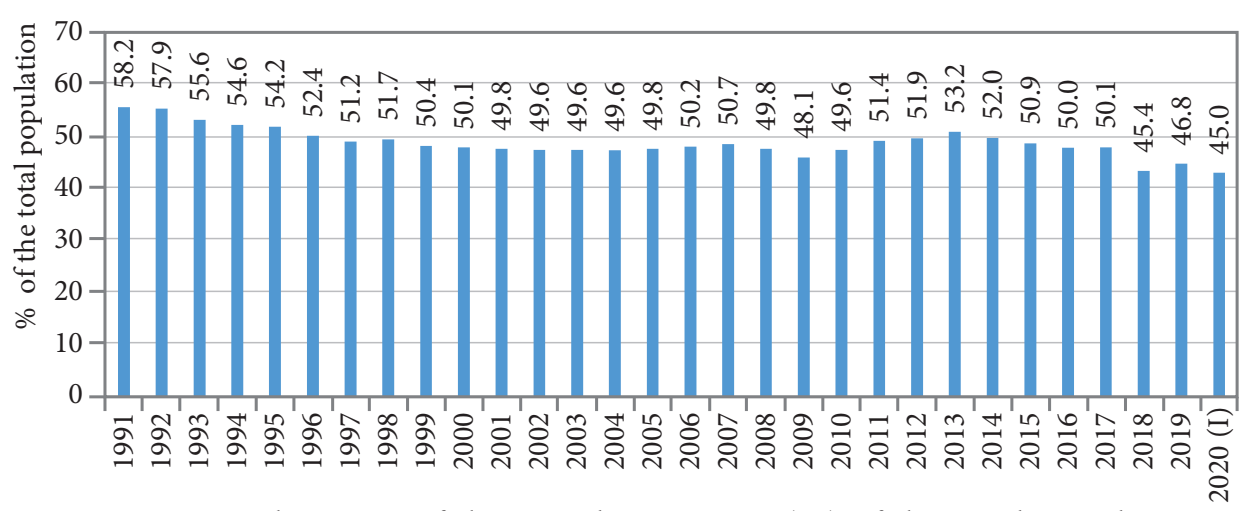

Figure 7. Employment of the population $15+(\%)$ of the total population Source: Database of NSS of Armenia www.armstat.am 
In addition, it should be noted that employment has been declining steadily over the past seven years, exacerbating the negative impact of the cuts in the face of the 2020 global pandemic.

In the light of growing unemployment, the obvious consequence was an increase in the unemployment rate in Armenia (Fig. 8). As of the end of the first quarter of 2020, the unemployment rate in the country was $19.8 \%$, which is higher than in 2019. At the moment, it is too early to judge the real consequences of the current crisis for the labor market, but we can say with confidence that those who employed in some sectors will inevitably fall into the rank of unemployed. First of all, this will affect the sphere of tourism and hotel services, to a certain extent, restaurant and related business, as well as some other areas that, if not immediately felt the reduction in economic activity in the country, then in the long term, will certainly have to accept the challenge of the coming crisis.

\section{Low incomes and high poverty rates}

Of course, initially low incomes of the population are already a big problem in terms of economic growth and development. However, in a crisis, the decline in household incomes becomes a serious test for government regulation.

In this sense, according to statistical indicators, the size of the average monthly wages in the first quarter shows growth, both in absolute and relative terms (see Fig. 9). The growth of wages

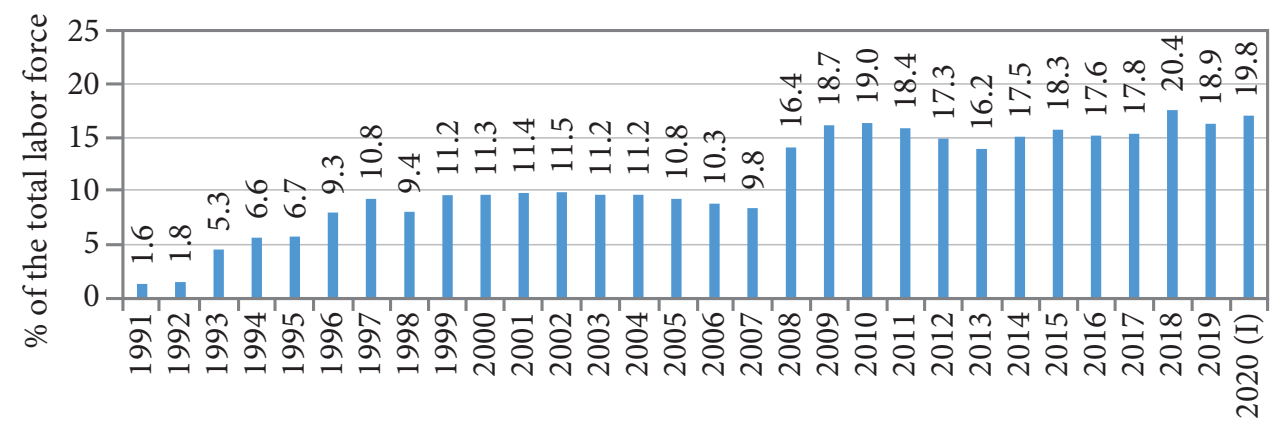

Figure 8. Unemployment (\% of the total labor force) Source: Database of NSS of Armenia www.armstat.am

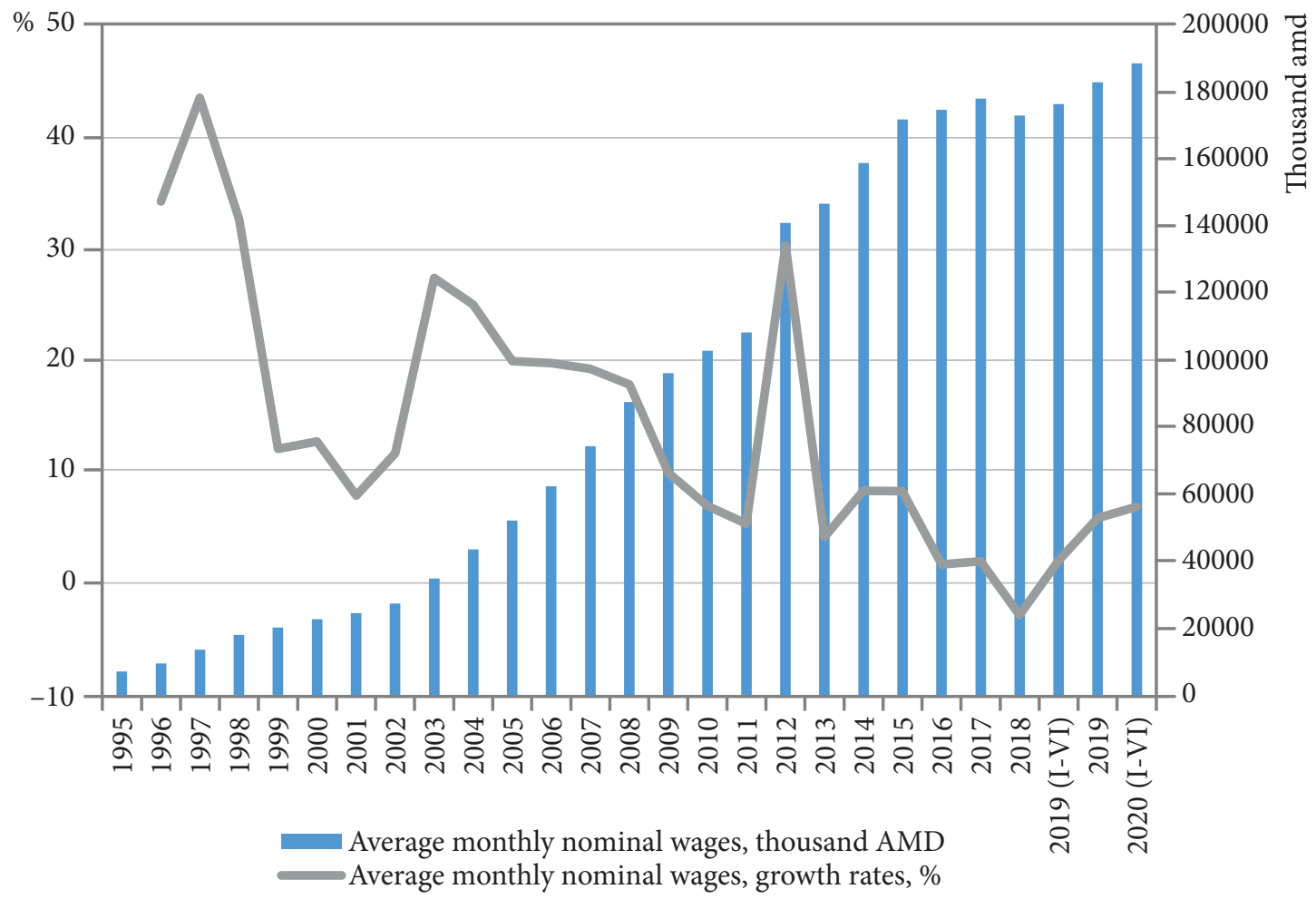

Figure 9. Average monthly nominal wages, in thousand AMD, 1995-2020 Source: Database of NSS of Armenia www.armstat.am 
in the first two quarters of 2020 was $6.8 \%$, against the background of the $2 \%$ growth in the same period of 2019. Thus, according to the Armenian National Statistical Service, in 2020 the average salary exceeded the indicators of 2019.

Nevertheless, in the structure of incomes of the Armenian population, in addition to wages, a rather significant share is occupied by private foreign money transfers.

As we can see in Figure 10, the inflow of private foreign cash transfers has declined significantly. Comparing the volume of transfer inflows in the first five months of 2020 with the same period last year, a decrease of $22.4 \%$ can be noted. At the same time, most of the reduction is associated with the reduction in the inflow of private foreign money transfers from the Russian Federation. It should also be noted that, given the seasonal nature of private foreign money transfers, one cannot but expect a significant reduction in such in- flows by the end of 2020, which will be caused by the natural consequences of the current pandemic in Russia and, therefore, by a reduction in the incomes of Armenian citizens living in the territory. In addition, over the past three months, there has been a large influx of population from Russia to Armenia, which will also affect the reduction in the inflow of private foreign money transfers.

\section{Implications for the State Budget of Armenia}

Against the background of a temporary but rather protracted suspension of economic activity, the natural reaction of governments was to actively stimulate the economy by injecting additional funds. However, the obvious result of such actions will be the expansion of public spending, which means, in the case of Armenia, an increase in the negative budget deficit.

Figure 11 shows the structure of public spending in Armenia: as we can see, social needs con-

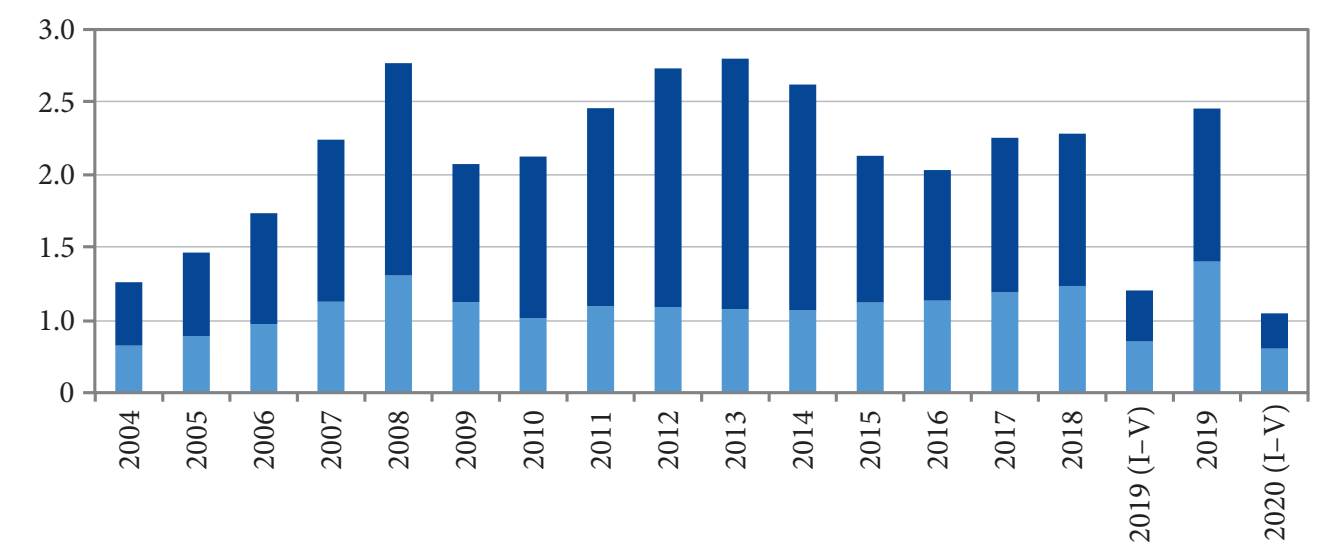

- Private transfers from abroad (mln USD) (Russia) — Private transfers from abroad (US \$ million) (others)

Figure 10. Private foreign cash transfers

Source: Database of the Central Bank of Armenia www.cba.am

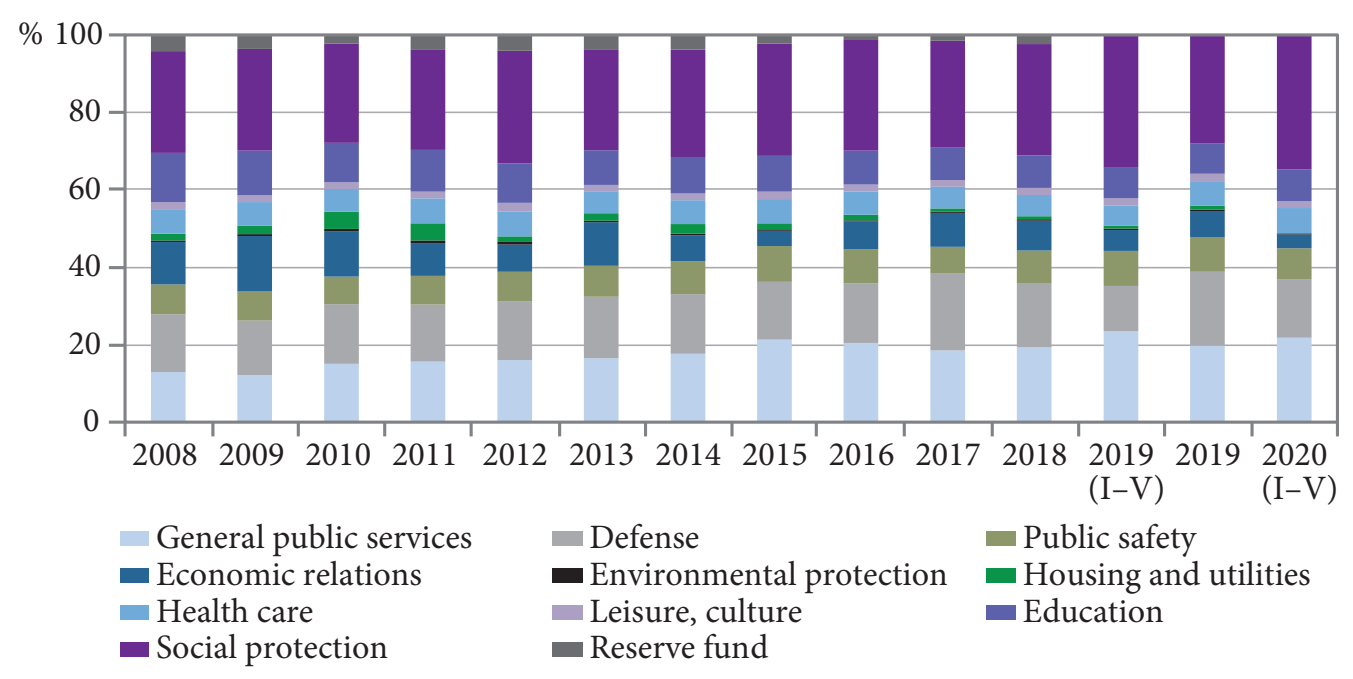

Figure 11. The structure of public expenditures in Armenia Source: Database of NSS of Armenia www.armstat.am 
stitute the largest share in public spending; they are followed by the public sector and defense. Taking into account the forced and significant downtime of most economic activity, almost all the states put great effort into stimulating national economies in order to prevent a serious decline in GDP. The Armenian government was guided by the same logic. As you can see from the above figure, the share of social spending as well as public sector spending has been markedly increased. Social spending was increased by $22 \%$ and public sector spending by $10.7 \%$ compared to the same period in 2019. Defense spending was increased by almost $56 \%$, and education spending was increased by $23.8 \%$. Finally, for obvious reasons, a significant increase in expenditures compared to the same period last year is demonstrated by the health care sector in the structure of state budget expenditures. Over the past five months, an increase in health care costs amounted to $48.5 \%$ compared to last year.

Thus, in general, state budget expenditures increased by $19.8 \%$ compared to the same period last year, while income growth was limited to only $0.8 \%$ growth. However, as statistics indicate, such a policy did not lead to an increase in the state budget deficit, but on the contrary, there is a noticeable reduction in this indicator compared to the same period last year. In other words, we can state a slight increase in the burden on the state budget. However, it is obvious that the situation may change by the end of the year.

\section{Anti-Crisis Program of the Government of Armenia}

The overwhelming majority of countries in the world have taken active and impressive measures to stimulate the economy. The size of injections from the budget varies from $2 \%$ to $10 \%$ of GDP. Of course, this primarily depends on the capabilities of the budget itself. In particular, for example, in Iran, support to the economy from the state budget amounted to about $10 \%$, in Russia about $6.5 \%$. Figure 12 shows the data on the state support to national economies in order to neutralize the consequences of the COVID 19 pandemic. As we can see, most of the developed countries spent large amounts to support the population and the real sector.

Most countries have devised and implemented anti-crisis measures, although some are still in the process of finalizing them. Armenia was no

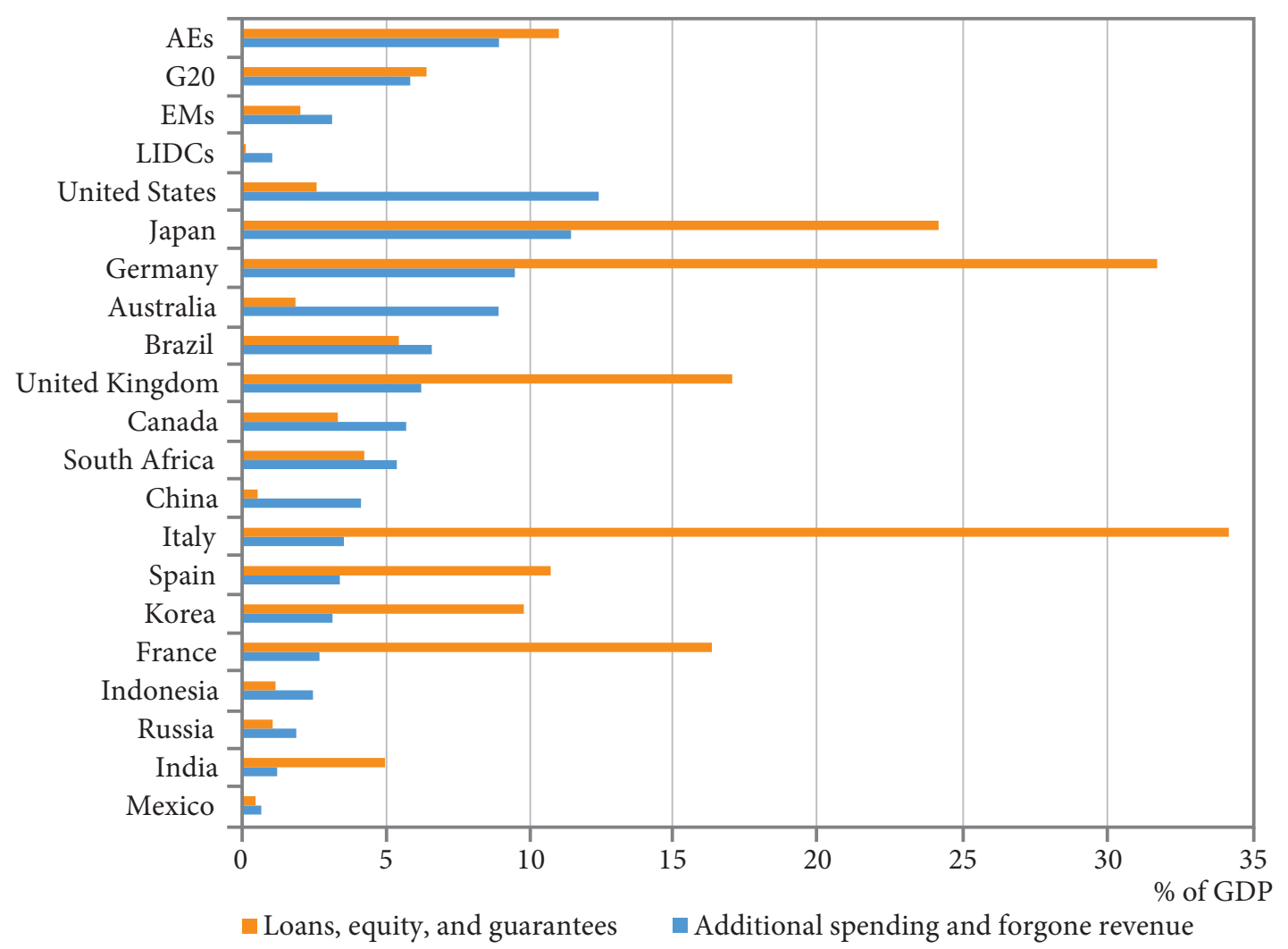

Figure 12. Fiscal measures of countries to support their economies, 2020, \% of GDP Source: International Monetary Fund https://www.imf.org/en/Publications/WEO/Issues/2020/06/24/WEOUpdateJune2020 
Table 1

Programs to address the economic impact of COVID-19

\begin{tabular}{|c|c|c|c|}
\hline & Target & Beneficiary & Support \\
\hline ACTION 1 & $\begin{array}{l}\text { Depends on the purpose } \\
\text { of spending }\end{array}$ & $\begin{array}{l}\text { resident economic entity with a good } \\
\text { credit and tax record }\end{array}$ & co-financing, refinancing, subsidies \\
\hline ACTION 2 & Agriculture & $\begin{array}{l}\text { resident economic entity or individual } \\
\text { with a good credit and tax record as well } \\
\text { as cooperative farms }\end{array}$ & $\begin{array}{l}\text { provided in the form of interest rate } \\
\text { subsidy; for cooperative farms - in } \\
\text { the form of co-financing, including } \\
\text { financial lease }\end{array}$ \\
\hline ACTION 3 & SMEs & $\begin{array}{l}\text { resident economic entity with a good } \\
\text { credit and tax record }\end{array}$ & $\begin{array}{l}\text { loans of up to AMD } 50 \text { million, de- } \\
\text { pending on turnover }\end{array}$ \\
\hline ACTION 5 & Effective Job Support & $\begin{array}{l}\text { resident economic entity with } 2-50 \\
\text { employees }\end{array}$ & $\begin{array}{l}\text { One-time grant, in the amount of the } \\
\text { salary of every } 5^{\text {th }} \text { employee }\end{array}$ \\
\hline ACTION 10 & $\begin{array}{l}\text { support for micro-enter- } \\
\text { prises }\end{array}$ & $\begin{array}{l}\text { economic entities registered as micro-en- } \\
\text { terprises }\end{array}$ & $\begin{array}{l}\text { one-off assistance of } 10 \% \text { of the turn- } \\
\text { over of goods and services provided in } \\
\text { the first quarter of } 2020 \text {, but not more } \\
\text { than twice the minimum wage }\end{array}$ \\
\hline ACTION 17 & high-tech industry & $\begin{array}{l}\text { Business entities that meet the criteria } \\
\text { specified in the Armenian Law on State } \\
\text { Support in the Sphere of Information } \\
\text { Technologies }\end{array}$ & $\begin{array}{l}\text { one-time grant to successful entrepre- } \\
\text { neurs }\end{array}$ \\
\hline ACTION 18 & effective job support & $\begin{array}{l}\text { economic entities registered in the Repub- } \\
\text { lic of Armenia that had } 2-100 \text { employees } \\
\text { between February 1, } 2020 \text { and April 30, } \\
2020\end{array}$ & one-timegrant \\
\hline ACTION 19 & $\begin{array}{l}\text { support for competitive } \\
\text { business ideas, entrepre- } \\
\text { neurial ideas developed } \\
\text { by beneficiaries seeking } \\
\text { to start a business from } \\
\text { scratch, promotion of } \\
\text { innovative business plans }\end{array}$ & $\begin{array}{l}\text { Armenia-registered economic entity or } \\
\text { individual entrepreneur }\end{array}$ & $\begin{array}{l}75 \% \text { of financial resources are provid- } \\
\text { ed as interest-free loans with a maturi- } \\
\text { ty of } 8 \text { years, } 25 \% \text { as grants }\end{array}$ \\
\hline ACTION 20 & Effective job support & $\begin{array}{l}\text { Business entities with } 2 \text { to } 100 \text { employees } \\
\text { as of March 1, } 2020 \text { through May 31, } 2020\end{array}$ & $\begin{array}{l}\text { one-time grant in the amount of the } \\
\text { salary of every } 5^{\text {th }} \text { employee }\end{array}$ \\
\hline
\end{tabular}

Source: The Government of the Republic of Armenia https://www.gov.am/ru/covid19./ (Accessed data July 1, 2020)

exception. At the first stage, the Government of Armenia developed an anti-crisis program consisting of 19 key points aimed at stabilizing the social and economic situation in the country. Subsequently, three more additional measures were proposed. All the measures were divided into two main groups ${ }^{4}$ : measures to neutralize the economic and social consequences of the coronavirus pandemic. According to preliminary estimates, the volume of state support will amount to 150 billion AMD or about 2.3\% of GDP. In the first two months of the anti-crisis program, 84.4 billion drams were distributed (Eurasian Economic Commission, 2020).

The key beneficiaries of the Economy Support Program were enterprises of the real sector, who suffered the most from the 6-week lockdown, micro-businesses, individual entrepreneurs and

\footnotetext{
${ }^{4}$ The Government of the Republic of Armenia. https:// www.gov.am/en/covid19./
}

firms in agriculture and the high-tech sector. Some measures were aimed at preserving the jobs in certain industries as well as compensating the costs of wages for workers who were in forced idle time. A complete list of anti-crisis measures is presented in Table 1.

The measures of social support included assistance to large families, families from disadvantaged groups, persons who lost their jobs during the pandemic, a compensation of utility costs to some social groups, compensation of tuition fees, partial compensation of incomes of the population in the sectors that have completely or partially suspended their activities during the lockdown, etc. A complete list of anti-crisis measures for social support is presented in Table 2 .

These measures to some extent allowed the government to cushion the effect of the pandemic in the beginning. However, the anti-crisis measures also had significant drawbacks. Most 
Programs to address the social impact of COVID-19

\begin{tabular}{|c|c|c|}
\hline & Beneficiary & Support type \\
\hline ACTION 4 & $\begin{array}{l}\text { family with a child under 14, if the parents or one of the parents have } \\
\text { lost their jobs in the period between March } 13 \text { and March } 25 \text { and } \\
\text { neither of the parents had a job as of March } 25\end{array}$ & $\begin{array}{l}\text { one-time support for each mi- } \\
\text { nor child in the amount of AMD } \\
100,000\end{array}$ \\
\hline ACTION 6 & citizens who lost their jobs on March 13-30, 2020. & $\begin{array}{l}\text { lump-sum assistance in the amount } \\
\text { of } 68,000 \text { AMD }\end{array}$ \\
\hline ACTION 7 & $\begin{array}{l}\text { Pregnant women who were unemployed as of March 30, and whose } \\
\text { husband lost his job between March 13-30, or unmarried pregnant } \\
\text { women }\end{array}$ & $\begin{array}{l}\text { one-time assistance in the amount } \\
\text { of AMD } 100,000\end{array}$ \\
\hline ACTION 8 & $\begin{array}{l}\text { individuals employed in the spheres listed below or self-employed on } \\
\text { March 13-30, 2020. }\end{array}$ & lump-sum assistance \\
\hline ACTION 9 & Families with a child aged $0-18$, if both parents are unemployed & $\begin{array}{l}\text { lump-sum assistance for each child } \\
\text { in the amount of AMD 26,500. }\end{array}$ \\
\hline ACTION 11 & $\begin{array}{l}\text { subscribers to natural gas and electricity supply contracts whose con- } \\
\text { sumer bills did not exceed } 10,000 \text { drams for natural gas consumption, } \\
5,000 \text { drams for electricity consumption as of February, } 2020 \text {. }\end{array}$ & $\begin{array}{l}\text { lump-sum assistance in the amount } \\
\text { of } 50 \% \text { of natural gas and electricity } \\
\text { consumed in February, 2020, respec- } \\
\text { tively }\end{array}$ \\
\hline ACTION 12 & $\begin{array}{l}\text { subscribers to natural gas and electricity supply contracts whose con- } \\
\text { sumer bills amounted to AMD } 10001-30000 \text { for natural gas, and } \\
\text { AMD } 5001-10000 \text { for electricity as of February, } 2020 \text {. }\end{array}$ & $\begin{array}{l}\text { lump-sum assistance in the amount } \\
\text { of } 30 \% \text { of natural gas and electricity } \\
\text { consumed in February, 2020, respec- } \\
\text { tively }\end{array}$ \\
\hline ACTION 13 & socially disadvantaged families & one-time assistance \\
\hline ACTION 14 & Graduate and postgraduate students of HEIs & lump-sum assistance \\
\hline ACTION 15 & $\begin{array}{l}\text { Armenian citizens or stateless persons residing in Armenia who may } \\
\text { wish to participate in the construction of riverbanks in the coun- } \\
\text { try's highlands co-organized by Hayantar State Non-Governmental } \\
\text { Organization, the Foundation for the Preservation of Wildlife and } \\
\text { Cultural Heritage }\end{array}$ & competitive wage \\
\hline ACTION 16 & $\begin{array}{l}\text { utility subscribers (natural gas, electricity, drinking water and (or) } \\
\text { drainage service). }\end{array}$ & lump-sum assistance \\
\hline ACTION 20 & $\begin{array}{l}\text { persons who from March } 1 \text { to June } 15 \text { were employed in the sectors } \\
\text { specified below (employees under civil law contract) or sole proprietors }\end{array}$ & $\begin{array}{l}\text { lump-sum assistance in the amount } \\
\text { of the minimum wage }\end{array}$ \\
\hline ACTION 21 & $\begin{array}{l}\text { people who lost their jobs and did not find a new one from March } 31 \\
\text { to June } 1,2020 .\end{array}$ & $\begin{array}{l}\text { one-time lump-sum support in } \\
\text { the amount of AMD } 68,000 \text {, paid } \\
\text { exclusively by money transfer to the } \\
\text { beneficiary's bank account }\end{array}$ \\
\hline
\end{tabular}

Source: The Government of the Republic of Armenia https://www.gov.am/ru/covid19./

of the measures were targeted at the most vulnerable groups, although ineffective administration has resulted in many potential beneficiaries not receiving the assistance they deserved. Another thing worth noting is the information asymmetry, when not all potential beneficiaries were sufficiently aware of their right to receive financial aid.

\section{Conclusions}

We analyzed the key factors of the economic slowdown in the light of the mid-term consequences of the pandemic. In addition, we considered the main measures taken by the Government of Armenia to overcome the economic problems associated with the pandemic.
As a result of the analysis of the macroeconomic situation in Armenia, we came to the conclusion that some sectors of the economy are currently very weak and require significant support from the government.

Among the key sectors that will probably be most severely affected by the crisis are exports and imports, economic diversification, the structure of the country's tax revenues and levels of public debt, incomes and levels of poverty, labor market efficiency, and investment in the economy.

At the same time, the anti-crisis program of the Government of Armenia currently only provides support for the economy in the short term. However, there is a need to develop an anti-crisis program that would address the mid- and long- 
term consequences of the pandemic. At the moment, the government is at the stage of developing and approving such a program. However, we believe that, given the urgency of the issue, measures to support the economy should be started immediately.

To summarize the above analysis, it should be noted that, of course, Armenia, like all other economies in the world, has suffered from the consequences of the coronavirus pandemic in 2020. However, at the moment it is too early to assess the real impact of the quarantine measures on economic growth and development both in Armenia and in the world. Of course, some predictions can already be made. However, given the degree of uncertainty associated with the end of the pandemic, it is difficult to fully rely on such forecasts. The only obvious fact is that the consequences will be long-term and will require significant intervention on the part of the government to maintain and restore the economy.

\section{References}

Antinyan, A., Bassetti, T., Corazzini, L., \& Pavesi, F. (2020). Trust in the Healthcare System and COVID-19 Treatment in the Developing World. Survey and Experimental Evidence from Armenia. Survey and Experimental Evidence from Armenia (June 1, 2020).

Brodeur, A., Gray, D. M., Islam, A., \& Bhuiyan, S. (2020). A Literature Review of the Economics of COVID-19.

Buck, T., Arnold, M., Chazan, G., \& Cookson, C. (2020, March 19). Coronavirus declared a pandemic as fears of economic crisis mount. Retrieved from: https://www.ft.com/content/d72f1e54-639611ea-b3f3-fe4680ea68b5.

Conti, V., Cafiero, C. \& Sánchez, M. V. Simulating rising undernourishment during the COVID-19 pandemic economic downturn. FAO, (2020). doi: 10.4060/ca8815en.

COVID-19: The Great Lockdown and its Impact on Small Business (2020). SME Competitiveness Outlook.Retrieved from International Trade Centre: https://www.intracen.org/uploadedFiles/intracenorg/Content/Publications/ITCSMECO2020.pdf

Furman, J., Geithner, T., Hubbard, G., \& Kearney, M. S. (2020). Promoting Economic Recovery After COVID-19. Washington: Economic Strategy Group, The Aspen Institute, pp. 16.

Global Economic Prospects. (2020, June). Washington, DC: World Bank. doi: 10.1596/978-14648-1553-9

Honorati, M., Yi, S., \& Choi, T. (2020). Assessing the Vulnerability of Armenian Temporary Labor Migrants during the COVID-19 Pandemic.

Jackson, J. K., Weiss, M. A., Schwarzenberg, A. B., Nelson, R. M. (2020). Global Economic Effects of COVID-19. Congressional Research Service, 74, pp. 117.

Keogh-Brown, M. R., Wren-Lewis, S., Edmunds, W. J., Beutels, P., \& Smith, R. D. (2010). The possible macroeconomic impact on the UK of an influenza pandemic. Health economics, 19(11), $1345-1360$.

Mishra, M. K. (2020). The World after COVID-19 and its impact on Global Economy, pp. 13.

Monitoring of the measures taken by the EAEU member states aimed at overcoming the negative consequences of the spread of coronavirus infection (COVID-2019). (2020). Retrieved from Eurasian Economic Commission: http://www.eurasiancommission.org/ru/covid-19/Documents/\%D0\%9C\% D0\%9E\%D0\%9D\%D0\%98\%D0\%A2\%D0\%9E\%D0\%A0\%D0\%98\%D0\%9D\%D0\%93\%20\%D0\%BD\%D0\%B0\%2018\%2005.pdf

Ozili, P. K., \& Arun, T. (2020). Spillover of COVID-19: impact on the Global Economy. doi: $\underline{10.2139 / \text { ssrn. } 3562570}$

Voskanyan, M. \& Galstyan, A. (2018). Assessment of the Prospects of Currency Integration with Russia: The Case of Armenia. Zhurnal novoy economiki (Journal of new economy), 19(5), 16-31. doi: 10.29141/2073-1019-2018-19-5-2

World economic outlook update (2020). Retrieved from International Monetary Fund: https:// www.imf.org/en/Publications/WEO/Issues/2020/06/24/WEOUpdateJune2020 


\section{Information about the author}

Mariam Voskanyan - Doctor of Economics, Associate Professor, Russian-Armenian University, Institute of Economics and Business, Head of the Department of Economics and Finance (0051, Armenia, Yerevan, O. Emin 123); e-mail: mariam.voskanyan@rau.am, voskanyanm@gmail.com

ARTICLE INFO: received July 20, 2020; accepted September 11, 2020

\section{Информация об авторе}

Восканян Мариам Амбарцумовна - доктор экономических наук, доцент, РоссийскоАрмянский университет, Институт экономики и бизнеса, заведующая кафедрой экономики и финансов (0051, Армения, Ереван, О. Эмина 123); e-mail: mariam.voskanyan@rau.am, voskanyanm@gmail.com

ИНФОРМАЦИЯ О СТАТЬЕ: дата поступления 20 июля 2020 г.; дата принятия к печати 11 сентября 2020 г. 